\title{
Mobile Learning in Higher Education for The Industrial Revolution 4.0: Perception and Response of Physics Practicum
}

\author{
https://doi.org/10.3991/ijim.v13i09.10948
}

\author{
Darmaji, Dwi Agus Kurniawan $\left.{ }^{\bowtie}\right)$, Astalini, \\ Artha Lumbantoruan, Sofia Christine Samosir \\ Universitas Jambi, Jambi, Indonesia \\ dwiagus.k@unja.ac.id
}

\begin{abstract}
Mobile learning is the use of technology in the learning process using tablets, PCs or smartphones. Online mobile learning based Provides opportunities for students to study anytime and anywhere. The use of a website as a learning medium broad Gives users access without downloading additional applications that are burdensome to the device. Therefore, the perception of physics education students is needed on the use of mobile learning in basic physics practicum II at the Universitas Jambi. This study aims to introduce new learning media that are more effective and flexible in the 4.0 digital era. Based on the results of the study, the perceptions of physics education study program students are in a good category with an average of 74.01 and a median of 75.00 and a mode of 75.00 .
\end{abstract}

Keywords-Science Process Skills, Technology in learning, M-Practicum Guidebooks, M-assessment, Physics Practicum

\section{Introduction}

Science process skills are one of the skills that support student learning. Science process skills are skills that provide the opportunity to explore through the study of physics [1]. In order to carry out the scientific approach, the prospective teachers need to be trained to carry out practices that can develop scientific skills or often known as Science Process Skills, Science process skills are divided into two, namely basic and integrated [2]. Science process skills are important for students to improve their ability to use scientific methods and acquire new knowledge. Because science process skills can be developed through practical activities necessary to guide the lab with the concept of thinking skills that can improve science process skills. If the lab activities using scientifically based guidelines, students will work more actively and build knowledge with self-contained so that it can improve the scientific attitude through practicum trial.

A practical guide book is a learning tool that petrified the success of the experiment during the practicum. Practicum will be qualified as a guide book to use work-based 
scientific support for development, knowledge, and skills of students [3]. Thermodynamics is one of the subjects of basic physics lab practicum II. Effective practical guide is a guide that can improve rational thinking skills of students [4]. When managed effectively practicum the students' science process skills will increase. To determine students' science process skills required at the time of the exercise of votes lab that has the appropriate assessment indicator science process skills. Rating performance assessment can improve science process skills by observing indicator, ask. With the science process skills assessment of students, lecturers will determine the development of science process skills students are not only the result of his skill alone.

Mobile learning is learning that can be simplified through the use of mobile devices [5]. Learning that puts students' skills can be developed through the use of mobile learning. Mobile learning is learning which is done when students are not in a predetermined fixed location [6]. Some use mobile learning can be used anytime and anywhere, more flexible and time-saving [7]. Then using mobile learning in basic physics lab manual II will be more effective and improve the skills of students. In addition to improving the system of education in learning, mobile learning can also be used as a medium in the assessment of so-called mobile learning assessment. Also, mobile devices are used to manage standard assessments and calculate scores [8]. One mobile device usage assessment system is a system of web assessment, web evaluation system has at least three main parts: the user, the server and the DBMS (database management system) [9]. Some of them are kind of DBMS Oracle, MySQL, PostgreSQL and MongoDB [10]. The use of electronic-based assessment can save substantially, it can be used in distance learning and self-training [11]. The use of mobile assessment will facilitate the assessment process science process skills in basic physics lab II.

One matter on the fundamental physics lab II is thermodynamical. Thermodynamics is a branch of physics science that studies the process whereby energy is transferred as heat and work [12]. The concept in thermodynamics is dynamic, so it takes creativity in solving problems in thermodynamics, so the concept of thermodynamics can be used to improve the skills of creative thinking of students [13]. Thermodynamics is a basic science that is very close to everyday life. Pengggunaan mobile learning on practical guide will facilitate learning anytime and anywhere. So that student learning will be more effective. Mobile assessment at the lab will support flexible than the paper-based assessment, provide feedback quickly, increase learning motivation. Then the use of mobile learning and mobile assessment will be very supportive to achieve the learning objectives on thermodynamics, to master the concepts of thermodynamics and be able to apply it to think higher and more effective in conducting assessments during the practicum. The study aims to determine students' perceptions of the use of mobile learning basic physics lab manual II and to evaluate the response of experts on the use of mobile learning and mobile assessment on fundamental physics lab II. 


\section{Literature Review}

\subsection{Science process skills}

Science process skills might be essential for physics education students in the success of the experiments in the laboratory. Students can draw Conclusions from the laws of physics by carrying out practical activities in the laboratory so that it is important to carry out laboratory activities to develop students' scientific achievements and science process skills[14] [15]. SPS is defined as the ability of the mental, physics, and competencies are used as learning tools necessary for effective science and technology such as problem-solving, individual development, and social development. Not only that, but students Also did the laboratory activities to produce new experiences and discover new things that can shape Reviews their scientific attitude [16]. Science process skills are also used to develop a scientific attitude to provide motivation in learning. Students' scientific attitudes are very influential in student learning [17]. When students have had good science process skills they have good thinking skills to solve problems related to science itself. Thinking skills used to create knowledge, solve problems and formulate results are meanings of science process skills [1] [18].SPS should be trained on student teachers, so students have the experience and the provision of learning that develops in implementing SPS because these skills should be repeated to form it into a better, Science process skills are divided into two basic skills and integrated skills. Observation, hypothesis formulation, prediction, investigation, the data interpretation, inference and result communication included by scientific process' activities[2]. As an educator prospective students must have a good science process skills, so that teachers also have a scientific attitude can be applied at the time of learning for scaling up students 'motivation and students' science process skills. Therefore, science process skills students need to be trained in science, particularly physics education.

\subsection{Mobile learning}

Mobile technology is breakthrough communication and information technology that was developed to meet the individual needs of the information. Mobile technology is so pervasive in modern society is that it changes the way someone accesses the volume of information [19]. Learning technologies to grow with the times, starting from the use of print media learning, computer-based learning to learn to use mobile media. We need to move, in the second wave of educational applications, to applications that foster digital experience cognitively active, very interesting, meaningful, interactive and socially in the context of learning objectives, rather than simply replicate and expand the old media such as books, worksheets, television, or even video games [20].The main purpose of learning technology to solve the problems arising from the lack of facilities in the learning activities. Along with the development of mobile technology is so widely attracted the attention of educators to utilize the field education so that the term mobile learning. Learning that Utilizes the latest technology or electronic type of learning is called mobile learning or m-learning [21][22]. Utiliza- 
tion of information technology in the learning process or in the process of assessment of students (in the form of repetition and duties), allowing students to test different place. The use of mobile learning can provide learning motivation for its users and Achieved the best learning status [23]. One of the advantages of the use of mobile learning as a learning medium that is the effectiveness of the size of mobile devices are convenient to take anywhere. Mobile learning provides an opportunity for anyone to study anywhere comfortably. These advantages provide opportunities for mobile learning to be developed and applied in learning. The survey results show that Moroccan students respond positively to mobile learning which leads to the possibility of Adopting a Moroccan mobile learning model in higher education [6]. Utilization of mobile learning devices provides access for students to learn anytime and anywhere, more flexible and time-saving.

\subsection{Practicum guidebooks and assessment instrument based mobile learning in basic physics practicum}

To support the practicum, students need a guidebook which should be based on aspects of science process skills. However, the lab printed guidebook is difficult to take because the size is thick. This refers to the conventional lab activities. Conventional lab activities are lab activities that have outdated (ancient) or traditional ways that are not in accordance with today's conditions. To overcome this, we need more effective learning media. The use of web-based learning media showed superiority to obtain the information online without having to download an application [11]. It aims to facilitate students to use practical guide books anytime and anywhere. If this is achieved, then created a learning medium that is innovative, effective, and efficient. Basic physics lab guide with the addition of digital concept will provide a new learning experience for students. Many studies support the view that the digital-based educational activities designed properly can be an important tool for efficient and effective learning [8]. It can be concluded that the digital media-based learning can realize the goal of learning that is innovative, effective and efficient.

To determine the effectiveness of the use of m-modules for training science process skills of students, an evaluation. Ratings utilizing technology has been widely used. The online-based assessment had been known in the assessment system at universities so that it can be accessed via smartphone [10]. The benefits of technology in the online ratings and influence on the performance and satisfaction of students allows students to monitor their understanding anytime, anywhere [24][25][26]. The use of technology as an assessment instrument providing knowledge to students and experience concrete. As well as the results of the assessment have high validity.

Mobile use in the evaluation of learning becomes the center of attention of educators today. The use of computers and smartphones in the evaluation of learning cannot be separated from the utilization of data management software. The database management software (DBMS) is used to store the Data or to manage the Data like MySQL DBMS [27]. In the assessment process, the team will produce a value provider of data, for example, student name, student identification number, lab materials, and the score the student science process skills. Therefore, the data obtained from the 
assessment requires software that can manage data on a large scale. In MySQL's DBMS can be seen all the data at the input of the administrator through the pages of the website. The use of the MySQL DBMS, which is a strong database development service management system, is able to store the data in the form of complete usage information [28]. The use of a MySQL DBMS database is suitable for data on a large scale. Data management via the MySQL DBMS provides convenience administrators to analyze the data that has been fed such as data basic science process skills of students. The data stored in a database called the software. M-assessment is used to determine the development of SPS physics students in practical activities. Event judge is deciding how big the action SPS students during lab experiments on material eg thermodynamics. Thermodynamics is a basic law of thermodynamics which consisted of four laws of thermodynamics [3]. Thermodynamics is one of the subjects at the basic physics lab II. Utilization of m-module, as well as m-assessment on thermodynamics lab activities, provide a new experience for both students as students doing practical work and students who provide ratings or observer.

\section{$3 \quad$ Research Methods}

This research is descriptive quantitative variables reviewing the student's perception of the physics education practicum guide books physics-based mobile learning and response variables experts to guide the use of basic physics lab and science process skills assessment based mobile learning. This study aims to introduce new learning media is more effective and flexible in the digital era 4.0 in basic physics lab II in Universitas Jambi by reviewing the student's perception of physics education and the response by media experts. Quantitative research is a research method that is based on the philosophy of positivism that is used to conduct a study of a population or a particular sample, data collection instruments, research and quantitative data analysis/statistics [29]. Furthermore, Data were obtained through a questionnaire of perception and response sheets were analyzed using descriptive statistics by reviewing the mean, mode, median, minimum value, maximum value, and percentage. The data has been processed, is expected to provide the information needed to explain that $\mathrm{m}$ learning as a learning medium more effectively used in basic physics lab II. The emergence of media-based learning mobile learning in higher education due to the demands of industrial revolution 4.0.

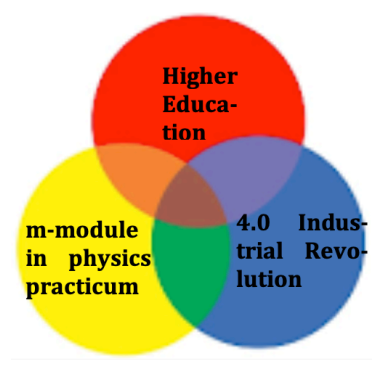

Fig. 1. Framework explicit theoretical research 
Revolution 4.0 is loaded with super-fast technology will bring changes to the physics' education system in Indonesia. Changes in the education system will impact the teachers' role as educators. Teacher guide has high competence to produce learners who are able to answer the challenges of the industrial revolution 4.0. By [45] mentions the competence of the first to be owned by prospective teachers in the revolutionary era 4.0 are:

- Educational competence, competence internet-based learning as basic skills

- Competence for technological commercialization, meaning that a teacher must have competencies that will bring their prospective educators have technology with entrepreneurship attitude on the work that is innovative

- Competence in globalization. Based on these

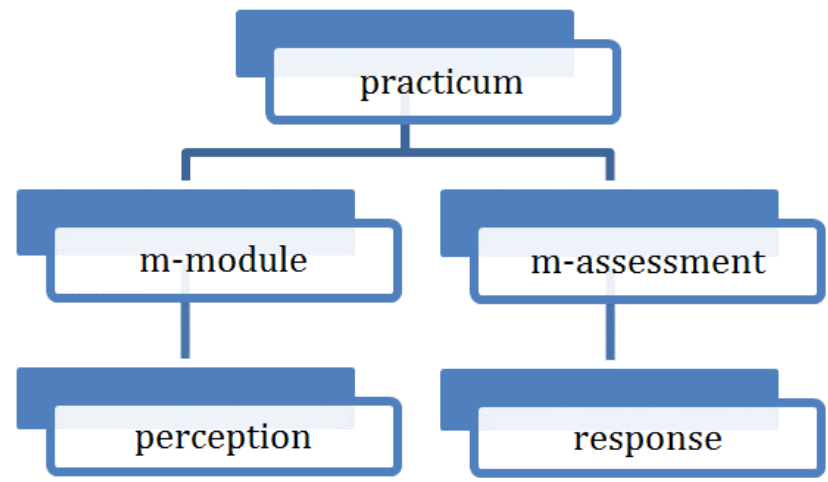

Fig. 2. Steps of data collection study physics education student perceptions and responses by media experts.

Practicum basic physics II lab within 50 minutes, with a series of activities of the division of the lab group, giving a demonstration of thermodynamics experiments, as well as practical implementation independently by students. In one group, consisting of three students who were randomly selected. Furthermore, the provision of thermodynamics demonstration experiment takes 15 minutes. After that, students do lab work independently within each group. Implementation of practical activities are steps that are still conventional lab activities, so the lab given time often do not meet the duration of the experiment thermodynamics. Therefore, it is necessary the use of learning technology, such as m-module and M-assessment to help the effectiveness of lab activities.

M-module and m-assessment is a medium of learning that utilizes mobile technology. In the implementation of modern lab activities, 50 minutes can be used very effectively. M-modules that can be accessed widely by students, providing an opportunity for students to learn anywhere and anytime, so step demonstration administration is not carried out as in conventional lab activities. Therefore, students have plenty of time to explore their own knowledge, so that students are able to find a physics concept independently. In addition, lecturers using m-assessment for the assessment 
of science process skills of students in the experimental thermodynamics. After doing lab activities, students are given a questionnaire of perception regarding the use of $\mathrm{m}$ module using a questionnaire that can be accessed through a link google forms. Furthermore, the interview to reinforce the perception of students. Post-lab, faculty given response sheets distributed immediately to investigate the response to the $\mathrm{m}$-media expert assessment.

A crucial step in this research is the conditioning class in practical implementation using $\mathrm{m}$-module and $\mathrm{m}$-assessment. The use of m-module is expected to support more independent students to acquire knowledge before doing laboratory experiments. It aims to look at the skills of the students in doing practical work, thereby granting the pre-lab demonstration is not necessary. In addition, the use of m-assessment helps lecturers to not only know the science process skills of students but also can monitor the progress of the science process skills of students. In addition to the lecturers, the use of m-assessment provides an opportunity for students to know and evaluate themselves in real-time.

The sampling technique in this study using total sampling. All members of the population were used as participants is total sampling techniques [30]. The study involved 89 students of physics education and media experts involving as many as four people. Manual data collection perceptions of physics-based mobile learning lab using perception questionnaire with five answer choices based on the Likert scale with the categories of strongly agree agree, undecided, disagree, and strongly disagree. This questionnaire was made through technology google form who then disseminated by utilizing social media. [31] also describes the use of an online questionnaire which he developed from other relevant research. Electronic data collection Provides a form of a data collection that is easy and fast and how to fill out the questionnaire Easily with steps:

- Accessing the Internet using a computer or mobile device

- Filling out the questionnaire

- Sending a questionnaire that has been refilled to Researchers [30]. Collecting data using a media expert response by the response sheet with four answer choices using on a Likert scale with the category is not very good, not excellent, good, and excellent.

Data collection method used was a questionnaire of perception, response and interview sheet. Management of a small group of surveys or questionnaires (called samples) to identify trends in attitudes, opinions, behaviors, or characteristics of a large group of people (called Populations) is a procedure in quantitative research [30]. Collecting data through interviews done to strengthen the student perceptions questionnaire data from physics education on the use of m-module in basic physics lab II.

Grain questionnaire students' perceptions of guide practical physics-based mobile learning as much as 20 statements (consisting of 10 statements positive and 10 negative statement. Perceptions of students physics education expected of a questionnaire in the form of answers to agree or disapproval by giving a score to each item a positive statement as follows: very agree $=5$, agree $=4$, undecided $=3$, disagree $=2$, and strongly disagree $=1$. The scoring for each negative item as follows: strongly agree $=$ 
1 , agree $=2$, hesitation $(\mathrm{R})=3$, disagree $(\mathrm{TS})=4$, and strongly disagree $(\mathrm{STS})=5$. Categorization of student perceptions questionnaire listed in table 1 .

Table 1. Level student perceptions

\begin{tabular}{|c|l|}
\hline Interval & \\
\hline $20.0-36.0$ & Very No Good \\
\hline $36.1-52.0$ & Not good \\
\hline $52.1-68.0$ & Enough \\
\hline $68.1-84.0$ & Well \\
\hline $84.1-100$ & Very good \\
\hline
\end{tabular}

As for the interviews were conducted with 22 respondents ie physics education students. Interviews were used in the form of a structured interview with the type of open-ended questions. Researchers ask some open-ended questions to clarify or learn more about the response of the respondent and the researcher must be an active listener to understand the clarification of the statement of respondents [32]. Respondents, students are led to give their views on mobile learning on its use in a physics lab. Item interview students' perceptions of 20 questions. The results of the interview are expected to strengthen the results of students' perceptions collected through questionnaires. Interviews conducted for almost 8 minutes for each student to dig deeper into their perceptions of mobile learning.

In response sheet by media experts involving six experts from physics education. This sheet consists of 20 statements with the three indicators of software engineering, instructional design, and visual communication, adapted from [33]. Response media experts expected in the form of an answer sheet good or not good to give a score for each item statement; is not very $\operatorname{good}(\mathrm{VNG})=1$, no $\operatorname{good}(\mathrm{NG})=2, \operatorname{good}(\mathrm{G})=3$, and very good $(\mathrm{VG})=4$. The categorization of responses is shown in table 2 .

Table 2. Level the response by media experts

\begin{tabular}{|l|l|}
\hline Interval & \\
\hline $20.0-35.0$ & Very No Good \\
\hline $35.1-50.0$ & Not good \\
\hline $50.1-65.0$ & Well \\
\hline $65.1-80.0$ & Very good \\
\hline
\end{tabular}

Data were analyzed using the mean value $(\mathrm{M})$, median $(\mathrm{Me})$, the mode $(\mathrm{Mo})$, the percentage, the range of the maximum value and the minimum value on the questionnaire perception and response sheet. Next to the interview data were analyzed by recording and classifying listen back every opinion has a similar meaning. Investigating further information, elaboration, and clarification of responses are some of the things Obtained from interviews [30]. Several arguments similar physics education students or dominant from the interview described succinctly and clearly. 


\section{$4 \quad$ Results and Discussion}

Advances in technology have recently been directed to the recognition of higher education teaching and learning mode are innovative and can help improve the process of learning [34]. One of the technologies developed in higher education is mobile-based learning. Mobile learning is something that is familiar to students of physics education. However, the use of m-module is reached by providing a new experience for the students of physics education. It was also described by [31] the use of $\mathrm{m}$ learning can improve communication between students and instructors, students can Obtain multimedia learning resources and materials on their mobile phones and provide new learning experiences. The novelty of this research was to determine the perception of physics education students on practical learning media, namely mobile learning based practice guidelines are built in accordance with the science process skills, and to determine the response of the media expert and assessment of science process skills-based mobile learning. This media provides a variety of features that help users get materials quickly and easily and provide effective assessment instruments because it can be accessed by anyone, anytime and anywhere, but taking into account aspects of science process skills. Description of physics education students' perceptions of the guide book based practicum mobile learning can be seen in Table 3

Table 3. Description of perceptions of physics education students on basic physics practicum's Guidebook based mobile learning

\begin{tabular}{|c|c|c|c|c|c|c|c|c|}
\hline \multicolumn{3}{|c|}{ Classifications } & \multirow{2}{*}{ Mean } & \multirow{2}{*}{ Median } & \multirow{2}{*}{ Mode } & \multirow{2}{*}{ Min } & \multirow{2}{*}{$\operatorname{Max}$} & \multirow{2}{*}{$\%$} \\
\hline Interval Score & Category & Total & & & & & & \\
\hline $20.0-36.0$ & Very Not Good & 0 & \multirow{5}{*}{74.01} & \multirow{5}{*}{75.00} & \multirow{5}{*}{75.00} & \multirow{5}{*}{52.00} & \multirow{5}{*}{91.00} & 0 \\
\hline $36.1-52.0$ & Not Good & 1 & & & & & & 1.1 \\
\hline $52.1-68.0$ & Enough & 26 & & & & & & 29.2 \\
\hline $68.1-84.0$ & Good & 42 & & & & & & 47.2 \\
\hline \multirow[t]{2}{*}{$84.1-100.0$} & Very Good & 20 & & & & & & 5.1 \\
\hline & & 89 & & & & & & 100 \\
\hline
\end{tabular}

Table 3 shows that the perception of physics education students are in both categories with the largest percentage of $47.2 \%$. The minimum value on physics education students' perceptions of 52.00 and a maximum value of 91.00 . The perception of the distribution of scores, the average score of students' perceptions of physics education is 74.01. Median of the perception of physics education students are at a score of 75.00. Mode on the perception of 75.00. 
Table 4. Description of response to the media expert physics guidebooks and assessment physics-based mobile learning.

\begin{tabular}{|c|c|c|c|c|c|c|c|c|}
\hline \multicolumn{3}{|c|}{ Classifications } & \multirow[b]{2}{*}{ Mean } & \multirow[b]{2}{*}{ Median } & \multirow[b]{2}{*}{ Mode } & \multirow[b]{2}{*}{ Min } & \multirow[b]{2}{*}{ Max } & \multirow[b]{2}{*}{$\%$} \\
\hline $\begin{array}{c}\text { Interval } \\
\text { Score }\end{array}$ & Category & Total & & & & & & \\
\hline $20.0-35.0$ & Very Not Good & 0 & \multirow{4}{*}{64.50} & \multirow{4}{*}{63.50} & \multirow{4}{*}{63.00} & \multirow{4}{*}{63.00} & \multirow{5}{*}{68.00} & 0 \\
\hline $35.1-50.0$ & Not Good & 0 & & & & & & 0 \\
\hline $50.1-65.0$ & Good & 3 & & & & & & 75 \\
\hline \multirow[t]{2}{*}{$65.1-80.0$} & Very Good & 1 & & & & & & 25 \\
\hline & & 4 & & & & & & 100 \\
\hline
\end{tabular}

Table 4 indicates the response of media experts who are in both categories with a percentage of $75 \%$. The minimum value in response to media experts of 63 and a maximum value of 68 . The average (mean) score distribution media expert response is at 64.50 while the median response data at 63.50. Mode value in the response data media expert at 63.00 .

Additionally conducted interviews with relevant physics education student guide book based practicum mobile learning in the laboratory as follows:

- "I was impressed with the look of a guide book based mobile learning lab that is not monotonous and blends color is attractive."

- "I like the use of a guide book based practicum mobile learning because it is easy to carry anywhere and help me read the material thermodynamic anywhere."

- "I like the idea linked guidebooks basic physics lab-based mobile learning more attractive than conventional physics lab guide books. Conventional physics lab guide book it is thicker and heavier. "

- "The use of basic physics lab guide books II-based mobile learning provides a lot of information for me and help me to do a practicum of thermodynamics."

- "Navigation on the guide book based practicum mobile learning can be used with a unique look."

- "Through the end of the initial inquiries and questions on basic physics lab guide books, II gives the motivation to work and dig deeper knowledge so that I can do a practicum well."

The guide book based practicum mobile learning becomes a medium of learning that can motivate student learning. Motivation to acquire knowledge and motivation to achieve certain things can be seen through the regularity and intensity of the use of technology as some independent activity [35]. Students tend to be more independent information by using m-learning as a result of their motivation from within themselves to improve competence in the field of education. This is evident from the interview in which the student explains that they are interested in using mobile learningbased practical guide.

Physics education student acknowledges the use of smartphones increase their knowledge.M-learning is supported by students to help them access different resources to gain knowledge and increase of flexibility in learning the which shows the positive attitude of students towards the benefits of using m-learning [36][37]. This 
shows that students realize that the use of smartphone a positive impact on students when used wisely. Some of the access they're doing is looking for information, browsing, downloading, reading e-books, listen to music, communications, streaming youtube. Respondents prefer android because it is easier to carry, and can be used anytime and anywhere. The development of technology in education is the use of android will be the media for mobile learning based learning is more flexible and can be used anywhere [31]. Other than that, use android has become the primary requirement for students to help them search for information (such as the download activity books, listen to audio books and access to learning youtube). Students recognize that the use of smartphones can be used for academic purposes such as obtaining information more instructive. Students take advantage of the android to access information that is education,

Students agree with the idea of practical guidance based learning using mobile learning to reason that the ease of obtaining information and its use efficient. Students understand that smartphones are more useful when used in learning. Electronic resources (non-print media) have replaced the print media in the digital era but the main thing to note is the training of young people who will be Able to think critically and reject negative influences from outside [38][39]. It is clear that students tend to get information using their smartphones than finding information in libraries.

In addition, also obtained information based on the response of media experts to guide books of basic physics lab II and science process skills assessment instrument based mobile learning that the use of these media fit for use. Mobile learning provides an opportunity for anyone to study anywhere comfortably [35]. Media experts recognize the effectiveness of the use of media-based learning mobile learning is applied to the basic physics lab II. Need to develop quality media such as m-learning modules to encourage students in the use of a wider and more effective [40]. The use of mobile learning based learning media provides the widest possible access to students to obtain information [41]. Media experts give their appreciation for the idea of using basic physics lab manual book-based mobile learning. In addition to material categorized coherent good, media experts were impressed with the addition of aspects of science process skills in it. Media experts also expressed their ideas to add an image element at every stage of the experiment on the procedure thermodynamic material in basic physics lab guide books II-based mobile learning. Media experts also expressed positive comments and have advised using this practical guide book on other materials.

Attempts to find out how effective the use of a guide book based practicum mobile learning in science process skills training is a necessary assessment of the science process skills of students. Evaluation is an activity to gather the information that will be used to decide on an accurate alternative to the make-decisions with certain criteria before the evaluation is identified Carried out [8]. Therefore, created science process skills assessment instruments based on mobile learning. Media expert also gave a positive response to the science process skills assessment instrument based mobile learning. Their assessment guidelines in this medium are described in a language easily understood. Data inputted student also is safe and confidential because this medium requires action "login" using a special username and password, which is only an observer, an observer to provide an assessment of science process skills of students 
and faculty who know. The use of the database on the website helps to manage the data is entered online [10]. Other than that, graphing feature science process skills in science process skills assessment instruments that facilitate the observer to draw conclusions about whether or not the science process skills of students in each class. Furthermore, graphs science process skills can also provide more detailed information such as information for each indicator science process skills both basic as well as integrated.

Given the perception of students to use m-module into effective learning media and can support practical activities to be better. This result is also supported by several previous studies in other countries such as [6][42]. Based on the result of the perception and response, it can be concluded that the use of the m-assessment module and highly effective in fundamental physics practicum II. The use of m-module and Massessment provide the education system changes at the Universitas Jambi. It needs to be an improvement in the global competence of teachers to achieve a better physics' education system, through physics education students' skills to use internet-based learning. Therefore, m-module and m-assessment should be used to support the competence of teachers in Indonesia in using information and communication technologies in the learning process.

Based on the findings it can be concluded that through this research there is new knowledge to competence ICT (Information and Communication Technologies) teachers in the management of learning. According to the standard of competence ICT (Information and Communication Technologies) [43] said that in developing the professionalism of teachers required their skills of digital literacy, the teacher must have the technological skills and knowledge of Web resources necessary to use technology to acquire the subject matter and pedagogical knowledge enhancements. Educator skills in using ICT as a learning resource and learning is the ability cyber media pedagogy [44]. Educators who have to support the implementation of the cyber pedagogy student center, which students tend to find his own knowledge. Cyber pedagogy is the result of the industrial revolution 4.0 that encourage the development of information and communication technology is present in learning. So as to enhance the ICT skills of teachers of physics, they must have skills in the use of information and communication technology to support virtual-based learning.

\section{Conclusion and Future Work}

Perceptions of students who fall into both categories at $47.2 \%$ with a mean of 74.01 and 75.00 mode. Data distribution perception of physics education students obtained a minimum value of 52.00 and 91.00 with a median of 75.00 . These results indicate that the perception of physics education students about basic physics lab guide books IIbased mobile learning with thermodynamic material is positive. In addition, the response by media experts on fundamental physics lab guide books II-based mobile learning and assessment instrument science process skills-based mobile learning in basic physics lab II is positive. It can be seen from the greatest percentage that is $75 \%$ 
with a mean of 64.50 and 63.00 mode. The distribution of scores responses given by media experts consisting of a minimum value of 63.00 .

In the future, we want to develop mobile learning based instructional media at Universitas Jambi to enhance the ICT skills to students as prospective educators in Indonesia. In addition, we want to develop assessment instruments are flexible and effective by utilizing mobile learning technology that cyber pedagogy competence of teachers is growing.

\section{Acknowledgement}

We would thank the chairman of physics education, which has given us the opportunity to work together. Also, we want to thank the chairman of the physics education laboratory at the Universitas Jambi, who has Provided the opportunity to be Able to conduct research at the Universitas Jambi physics laboratory education. Besides that, thank you to all of the physics education student and media experts have Participated in this research.

\section{$7 \quad$ References}

[1] Karadan, M., \& Hameed, D. A. (2016). Curricular Representation of Science Process Skills in Chemistry. IOSR Journal of Humanities and Social Science, 21(08), 01-05. https://doi.org/10.9790/0837-2108120105

[2] Yumusak, G. K. (2016). Science Process Skills in Science Curricula Applied in Turkey. Journal of Education and Practice, 7(20), 94-98

[3] Myers, R. L. (2013). The Basics of Physics. London: Greenwood Press. https://doi.org/ $\underline{10.5860 / \text { choice. } 43-6587}$

[4] Suprianto, Kholida, S., I., Andi, H., J., \& Mahardika, I., K. (2018). The Effectiveness Of Basic Physics Experiment Module Based On Guided Inquiry Model In Improving Hard Skills And Soft Skills Of Prospective Physics Teachers. Jurnal Pendidikan Fisika Indonesia, 14(2), 52-59, https://doi.org/10.15294/jpfi.v14i2.11579

[5] Oyelere, S. S., Suhonen, J., \& Sutinen, E. (2016). M-Learning: A New Paradigm of Learning ICT in Nigeria. International Journal of Interactive Mobile Technologies (IJIM), 10(1), 35. https://doi.org/10.3991/ijim.v10i1.4872

[6] Zidoun, Y., El arroum, F.-Z., Talea, M., \& Dehbi, R. (2016). Students' Perception About Mobile Learning in Morocco: Survey Analysis. International Journal of Interactive Mobile Technologies (IJIM), 10(4), 80. https://doi.org/10.3991/ijim.v10i4.5947

[7] Woodill, G. (2011). The Mobile Learning Edge. USA: The McGraw-Hill Companies.

[8] Stathopoulou, A., Karabatzaki, Z., Kokkalia, G., Dimitriou, E., Loukeri, P. I., Economou, A., \& Drigas, A. (2018). Mobile Assessment Procedures for Mental Health and Literacy Skills in Education. International Journal of Interactive Mobile Technologies (IJIM), 12(3), 21. https://doi.org/10.3991/ijim.v12i3.8038

[9] Darmawan, D., Suryadi, E., \& Wahyudin, D. (2016). Smart Digital for Mobile Communication Through TVUPI Streaming for Higher Education. International Journal of Interactive Mobile Technologies (IJIM),13(5), https://doi.org/10.3991/ijim.v13i05.10286

[10] Abou El-Seoud, S., El-Sofany, H., \& Taj-Eddin, I. (2016). Mobile Applications and Semantic-Web - A case study on Automated Course Management. International Journal 
Paper-Mobile Learning in Higher Education for The Industrial Revolution 4.0: Perception and ...

of Interactive Mobile Technologies (IJIM), 10(3), 42. https://doi.org/10.3991/ijim.v10i3. $\underline{5770}$

[11] Webb, S., Malik, M., \& Wilson, M. (2015). Can Web Thin Clients be used to Create Flexible Assessment Spaces in a Higher Education Setting?. International Journal of Interactive Mobile Technologies (IJIM),9(4),69-73. https://doi.org/10.3991/ijim.v9i4.4681

[12] Giancoli, D., C. (2013). Physics Principles with applications. Amerika : Pearson.

[13] Hakim, A., Liliasari, A., Setiawan, Saptawati, G., A., P. (2017). Interactive Multimedia Thermodynamics to Improve Creative Thinking Skill Of Physics Prospective Teachers. Jurnal Pendidikan Fisika Indonesia, 13(1), 33-40. https://doi.org/10.15294/jpfi.v13i1.8447

[14] Kapucu, S. (2017). Predicting physics achievement: attitude towards physics, self-efficacy of learning physics, and mathematics achievement. Asia-Pacific Forum on Science Learning and Teaching, 18(1), 1-22.

[15] Liew, S. S., Lim, H. L., Saleh, S., \& Ong, S. L. (2018). Development of Scoring Rubrics to Assess Physics Practical Skills. EURASIA Journal of Mathematics, Science and Technology Education,(ISSN:1305-8223), 15(4), em 1691. https://doi.org/10.29333/ejmste/103074

[16] Astalini, Kurniawan, D. A., Perdana, R., \& Pathoni, H. (2019). Identifikasi Sikap Peserta Didik terhadap Mata Pelajaran Fisika di Sekolah Menengah Atas Negeri 5 Kota Jambi. Unnes Physics Education Journal, 8(1), 34-43. Retrieved from https://doi.org/10.15294 upej.v8i1.29510

[17] Astalini, Kurniawan, D.A., Perdana, R., \& Kurniasari, D. (2018). Identification of Student Attitudes toward Physics Learning at Batanghari District High School. The Educational Review, USA, 2(9), 475-484. https://doi.org/10.26855/er.2018.09.003

[18] Kusuma, M. D., Rosidin, U., Abdurrahman, A., \& Suyatna, A. (2017). The Development of Higher Order Thinking Skill (Hots) Instrument Assessment In Physics Study. IOSR Journal of Research \& Method in Education (IOSRJRME), 07(01), 26-32. https://doi.org/10.9790/7388-0701052632

[19] Udanor, C. N., \& Oparaku, O. U. (2016). A Performance Evaluation of a Multi-Agent Mobile Learning System. International Journal of Interactive Mobile Technologies (IJIM), 10(2), 10-18. https://doi.org/10.3991/ijim.v10i2.4873

[20] Papadakis, S., \& Kalogiannakis, M. (2017). Mobile educational applications for children: what educators and parents need to know. Int. J. Mobile Learning and Organisation, 3(11), 256-277. https://doi.org/10.1504/ijmlo.2017.085338

[21] Ebrahim, H. S. , Ezzadee, K., \& Alhazmi, A. K. (2015). Acquiring Knowledge through Mobile Applications. International Journal of Interactive Mobile Technologies (IJIM), 9(3), 71-74. https://doi.org/10.3991/ijim.v9i3.4495

[22] Sulisworo, D., Ishafit, I., \& Firdausy, K. (2016). The Development of Mobile Learning Application using Jigsaw Technique. International Journal of Interactive Mobile Technologies (IJIM), 10(3), 11. https://doi.org/10.3991/ijim.v10i3.5268

[23] El-Seoud, M. S., Karkar, A., Ja'am, J. M., \& Kamar, O. H. (2015). A Pictorial Mobile Application for Improving Communication Skills in Non-Verbal Autism. International Journal of Interactive Mobile Technologies (IJIM), 9(4), 49-55. https://doi.org/10.39 91/ijim.v9i4.4699

[24] Ye, H. (2015). Assessment of E-learning system in higher education based on hesitant fuzzy information with incomplete attribute weights. International Journal of Emerging Technologies in Learning, 10(8), 34-37. https://doi.org/10.3991/ijet.v10i8.5217

[25] Jeljeli, R., Alnaji, L., \& Khazam, K. (2018). A comparison between moodle, Facebook, and paper-based assessment tools: Students' perception of preference and effect on performance. International Journal of Emerging Technologies in Learning, 13(5), 86-98. https://doi.org/10.3991/ijet.v13i05.8091 
Paper-Mobile Learning in Higher Education for The Industrial Revolution 4.0: Perception and ...

[26] Bahati, B., Fors, U., Hansen, P., Nouri, J., \& Mukama, E. (n.d.). Measuring Learner Satisfaction with Formative e -Assessment Strategies. 14(7), 61-79. https://doi.org/10.3991/ijet.v14i07.9120

[27] Liu, J., \& Fu, R. (2018). Development of an Accounting Skills Simulation Practice System Based on the B/S Architecture. International Journal of Emerging Technologies in Learning, 13(10), 134-145. https://doi.org/10.3991/ijet.v13i10.9459

[28] Gong, Y. (2018). Design and Implementation of English for Academic Purpose Online Learning System Based on Browser/Server Framework. International Journal of Emerging Technologies in Learning, 13(3), 141-153. https://doi.org/10.3991/ijet.v13i03.8399

[29] Cohen, L., Manion, L., \& Morrison, K. (2007). Research Methods in Education. Routlege.

[30] Creswell, J. W. (2012). Educational Research: Planning, Conducting and Evaluating Quantitativ and Qualitativ Research. Lincoln: University of Nebraska.

[31] AlHajri, R., Al-Sharhan, \& AL-Hunaiyyan, A. (2017). Students' Perceptions of Mobile Learning: Case Study of Kuwait. International Journal of Educational and Pedagogical Sciences. 2(11). 371-374

[32] Proudfoot, D. E., \& Kebritchi, M. (2017). Scenario-Based Elearning And Stem Education : A Qualitative Study Exploring The Perspectives of Educators. International Journal of Cognitive Research in Science, Engineering and Education, 5(1), 7-18. https://doi.org/10. 5937/IJCRSEE1701007P

[33] Sari, A., P., \& Setiawan, A. (2018). The Development Of Internet -Based Economic Learning Media Using Moodle Approach. International Journal Of Active Learning, 3(2), 100-109.

[34] Papadakis, S., Kalogiannakis, M., Sifaki, E., \& Vidakis, (2018). Access Moodle Using Smart Mobile Phones. A Case Study in a Greek University. ICST Institute for Computer Sciences, Social Informatics and Telecommunications Engineering, 376-385. https://doi.org/10.1007/978-3-319-76908-0 36

[35] Irina, A., Irina, B., Anastasia, G., \& Elena, D. (2019). Active Learning Technologies In Distance. International Journal of Cognitive Research in Science, Engineering and Education, 7(1), 85-94. https://doi.org/10.5937/ijcrsee1901085A

[36] Adel Ali, R., \& Rafie Mohd Arshad, M. (2017). Investigating the Perception of Students Regarding M-Learning Concept in Egyptian Schools. International Journal of Interactive Mobile Technologies (IJIM), 11(6), 112. https://doi.org/10.3991/ijim.v11i6.7361

[37] Marzouki, O. F., Idrissi, M. K., \& Bennani, S. (2017). Effects of Social Constructivist Mobile Learning Environments on Knowledge Acquisition: A Meta-Analysis. International Journal of Interactive Mobile Technologies (IJIM), 11(1), 18. https://doi.org/ 10.3991/ijim.v11i1.5982

[38] Vyas, N., \& Nirban, V. (2014). Students' Perception on the Effectiveness of Mobile Learning in an Institutional Context. ELT Research Journal, 3(1), 26-36. Retrieved from http://dergipark.gov.tr/eltrj/issue/5481/74444

[39] Zhdanko, A. (2019). Identification Of Cognitive Manipulations That Have The Greatest Impact On Students In The Internet. International Journal of Cognitive Research in Science, Engineering and Education (IJCRSEE), 7(1), 35-42. https://doi.org/10.5937/ ijcrsee $1901035 \mathrm{Z}$

[40] Papadakis, S., Kalogiannakis, M., Sifaki, E., \& Vidakis, N. (2018). Evaluating Moodle use via Smart Mobile Phones. A case study in a Greek University. EAI Endorsed Transactions on Creative Technologies, 5(16), https://doi.org/10.4108/eai.10-4-2018.156382

[41] Nkonko, E. K. Chiliya, N., Chuchu, T., \& Ndoro, T. (2019). An Investigation into the Factors Influencing the Purchase Intentions of Smart Wearable Technology by Students. In- 
ternational Journal of Interactive Mobile Technologies, 13(5), 15-29. https://doi.org/10. 3991/ijim.v13i05.10255

[42] Omar, M. F., Roshidi, S. R. A., Jamil, J. M., Kamal, F. M., Nawi, M. N. M. N., \& Radzuan, K. (2019). Towards Designing Tools for Universities' R\&D Performance Measurement on Mobile Platform. International Journal of Interactive Mobile Technologies (IJIM), 13(4), 178-187. https://doi.org/10.3991/ijim.v13i04.10547

[43] UNESCO. (2008). Ict Competency Standards For Teachers. United Kingdom:UNESCO

[44] Ngampornchai, A., \& Adams, J. (2016). Students' acceptance and readiness for E-learning in Northeastern Thailand. International Journal of Educational Technology in Higher Education, 13-34. https://doi.org/10.1186/s41239-016-0034-x

\section{Authors}

Darmaji is a lecturer and member of the ASPS Research Group (Attitudes to Physics and Science Processing Skills). Physics Education Program, Universitas Jambi, Jalan Raya Jambi - Ma. Bulian, KM 15, Mendalo Indah, Jambi, 36361, Indonesia. His research interests include E-Assessment and Evaluation especially in Attitudes Towards Physics and Processing of Science Skills. Regarding the benefits of science process skills namely as a science students can develop with a process skills approach. Learning through process skills will provide opportunities for students to work with science (Email: darmaji@unja.ac.id)

Dwi Agus Kurniawan is a lecturer and member of the ASPS Research Group (Attitudes Towards Physics and Science Processing Skills). Physics Education Program, Universitas Jambi, Jalan Raya Jambi - Ma. Bulian, KM 15, Mendalo Indah, Jambi, 36361, Indonesia. His research interest includes E-Assessment and Evaluation especially in Attitudes Towards Physics and Processing of Science Skills (Email: dwiagus.k@unja.ac.id)

Astalini is an associate professor and ASPS Research Group Leader (Attitude Towards Physics and Science Processing Skills). Physics Education Program, Universitas Jambi, Jalan Raya Jambi - Ma. Bulian, KM 15, Mendalo Indah, Jambi, 36361, Indonesia. His research interests include E-Assessment and Evaluation especially in Attitudes Towards Physics and Science Processing Skills. The importance of attitude can form a real character, if our attitude is negative, then our behavior will look negative too, and vice versa, if our attitude is positive, then our behavior will also be positive. Regarding the benefits of the science process skills that students can develop with a process skills approach. (Email: astalinizakir@unja.ac.id)

Artha Lumbantoruan is a final student and a member of the ASPS Research Group (Attitudes Towards Physics and Science Processing Skills). Educational Science Program, Universitas Jambi, Jalan Raya Jambi - Ma. Bulian, KM 15, Mendalo Indah, Jambi, 36361, Indonesia. His research interest includes E-Assessment and Evaluation especially in Attitudes Towards Physics and Science Processing Skills (Email: artha.lumbantoruan16@gmail.com)

Sofia Christine Samosir is a final student and a member of the ASPS Research Group (Attitudes Towards Physics and Science Processing Skills). Educational Science Program, Universitas Jambi, Jalan Raya Jambi - Ma. Bulian, KM 15, Mendalo 
Paper-Mobile Learning in Higher Education for The Industrial Revolution 4.0: Perception and ...

Indah, Jambi, 36361, Indonesia. His research interest includes E-Assessment and Evaluation specifically in Attitudes Towards Physics and Science Processing Skills (Email: sopiasamosir@gmail.com)

Article submitted 2019-05-29. Resubmitted 2019-07-13. Final acceptance 2019-07-13. Final version published as submitted by the authors. 